\title{
The Millennials Metacognitive Assessment toward Flood-Disaster in Semarang City
}

\author{
Erni Suharini and Edi Kurniawan \\ Universitas Negeri Semarang, Indonesia
}

Received: 2020-10-05 Accepted: 2021-03-30

\section{Keywords:}

disaster preparedness;

flood disaster;

Millennials;

metacognitive

Correspondent email: erni.suharini@mail.unnes.ac.id

\begin{abstract}
Disaster management action should be built up through developing metacognitive and action skills. The metacognitive strategy includes aspects of knowledge about when and how to use it by type, specific technique, and response that are assumed related to deal with disasters. Therefore, this study was aimed to assess the metacognitive abilities of millennials who are affected by disasters and its relation to disaster management. This study used an observatory exploration and inventory (EOI) method involving 248 respondents in flood-prone areas in the city of Semarang. Data were obtained using a questionnaire-based Guttman model electronic survey as many as 52 statements to inventory metacognition abilities and 48 statements related to actions in flood disaster management. Data were analyzed using Pearson's linear and regression analysis. The non-parametric analysis: Kruskal-Wallis test was run to distinguish metacognitive scores in dealing with food-related problems among millennials groups. For metacognitive awareness, the cognition knowledge was higher than controlling knowledge $(\mathrm{p}<0.05)$. The highest score of metacognitive variables was debugging strategy, which represents a corrective attitude. As described in the value of conditional knowledge, the ability to think fast shows that the millennials are quickly responding and understanding how to act. Most of the respondent actively involved in mitigation and rehabilitation as a volunteer in youth-events such us mangrove planting and cleaning plastic-trash in coastal areas. But, lack involvement of millennial in arranging flood-disaster management make less youth's responsibility during the disaster. It should be overcome to create a comprehensive approach to community-based disaster resilience.
\end{abstract}

๑2021 by the authors. Licensee Indonesian Journal of Geography, Indonesia

This article is an open access article distributed under the terms and conditions of the Creative Common

Attribution(CC BY NC) licensehttps://creativecommons.org/licenses/by-nc/4.0/.

\section{Introduction}

Indonesian National Board for Disaster Management has recorded 18,747 disaster occurs for the last ten years, which flood is the highest disaster reaches $37.4 \%$ in Indonesia (BNPB, 2021). Semarang City is the capital city of Central Java with the areas of about $374 \mathrm{~km}^{2}$, an altitude less than 3.5 to 200 meters above sea level (masl) (Nugraha et al., 2017; Nugraha et al., 2017; Tjahjono et al., 2018; Yulianto et al., 2019). Flash-floods and tidal-flood threaten approximately $40 \%$ of the lowland areas in Semarang City by sea level rises. In another part, more problems worsen flood disaster caused by high population around riverbank areas (Suharini et al., 2017). During 2018, at least $18 \%$ of the total disasters in Semarang City are flood disasters, include flash floods and inundation (BPBD, 2021). The riverbank condition, such as land occupation and land conversion, narrows watersheds and water catchment areas and increases flood events in Semarang City (Buchori et al., 2018; Indrayati et al., 2018). It indicates that high occupation in watersheds may weaken the rivers' carrying capacity (Naubi et al., 2017; Roy et al., 2016) . Besides that problems, high exploration of gases and groundwater extraction make land subsidence that surges flood risk (Chaussard et al., 2013). Increased population, high business activity, and resources may lead people migration and occupation that increase environmental damage and disasters (Hapsari \& Zenurianto, 2016; Mark, 2017; Suharini et al., 2017)
Community-based resilience has developed in Semarang City to help them confronting flash floods and inundation problems. It has leverage community participation in early warning of flood disaster (Sari \& Prayoga, 2018), even though it still needs more improvement, especially in community understanding and awareness of their needs. Poor knowledge and responses about flood-disaster in the community reduce awareness and increase their vulnerability to the economic and social life (Cox \& Hamlen, 2015). Whereas the community has indispensable roles in improving disaster resilience and disaster risk reduction by developing collaborative strategies involving millennials. Millennials are a demographic cohort in the community that grows in the $21^{\text {st }}$ century that is familiar with their digital technology usage and social media (Janicke-Bowles et al., 2018). Community resilience can be generated by collaboration and raising millennials knowledge (Nifa et al., 2017) about resources, preparedness strategies, and strengths (Rico, 2019) make the community possible to maintain and prepare themselves through mitigation, adaptation, and rehabilitation of flood disasters (Liu et al., 2018; O’Neill et al., 2016). However, as one of the community's main motors, the millennials mostly lack understanding in disaster mitigation and adaptation that makes them more vulnerable (Fothergill, 2020). In the current research, the youth or millennials themselves are enthusiastic about being involved in the disaster management 
process (Cox et al., 2019; Fletcher et al., 2016). Hence, it is needed to identify their knowledge of plan, action, and thinking over flood-disaster, to make disaster management strategy among community elements easier.

Metacognition is well known as an ability to create plans or strategies for approaching and solving problems, evaluating and giving feedback on the results, and modifying approaches as desirable (Ozsoy et al., 2009). Metacognition is also correlating with how the millennials expected to be independent in learning and action, be honest with each other's abilities, both weaknesses, and strengths, and dare to try new strategies to explore knowledge and improve their abilities (Kavousi et al., 2019; Shea \& Frith, 2019). Metacognition is essential to possess because it can also relate to measuring a conscious effort to survive, especially in nuisance (Kudesia, 2019). Metacognition may refer to community awareness and disaster preparedness, even though it needs a long list of things to understand the importance of metacognition in community disaster awareness (Ganapati \& Mostafavi, 2018).

Metacognition is also directly reflecting a high-order thinking skill that may build up in the community experiences to respond to the surrounding phenomenon (Zweers, 2019). Furthermore, previous researches on millennials in Semarang City shows a low level of high-level thinking scores shows a lack of concern for flood disasters (Rahmayanti et al., 2020). This indicates that knowledge of flood disaster preparedness, including mitigation, adaptation, and emergency response, is not yet massively widespread (Suharini et al., 2020). Therefore, increasing the person's capacity for natural disasters awareness among the community may affordable to be gained using metacognitive strategy. There needs to be a systematic effort to increase public understanding of flood disasters through metacognitive strategy. Therefore, in this research, we analyzed the millennials' metacognitive knowledge to depicts how they develop their expertise in disaster management actions and overcome the flood-disaster damage effect.

\section{Method}

This research was conducted using an exploratory observational method to examine the role and ability of millennials' metacognitive in dealing with flood disasters. A total of 16 districts in Semarang City were selected as a research site because 1) it frequently severe of the river and coastal flooding, 2) there were several communities basedprograms settled to overcome flooding effect that needed to be monitored and evaluated. The data was obtained using field observation and closed-questionnaire using electronic surveys: Google forms.

This research was involved 248 respondents, ages 14-24 years old. We assumed the respondents of these ages are developing their thinking skills (Ivanova, 2019), proper information management, and digital native (Koumachi, 2019). So, it is the appropriate standpoint to determine how far their thinking skill has developed. As many as 108 respondents were involved from 11 districts of the no-or-less potential area affected by the flood, and 140 respondents participated from five highly-affected districts by flash-flood and tidal-flood (Table 1). The respondents were involved by

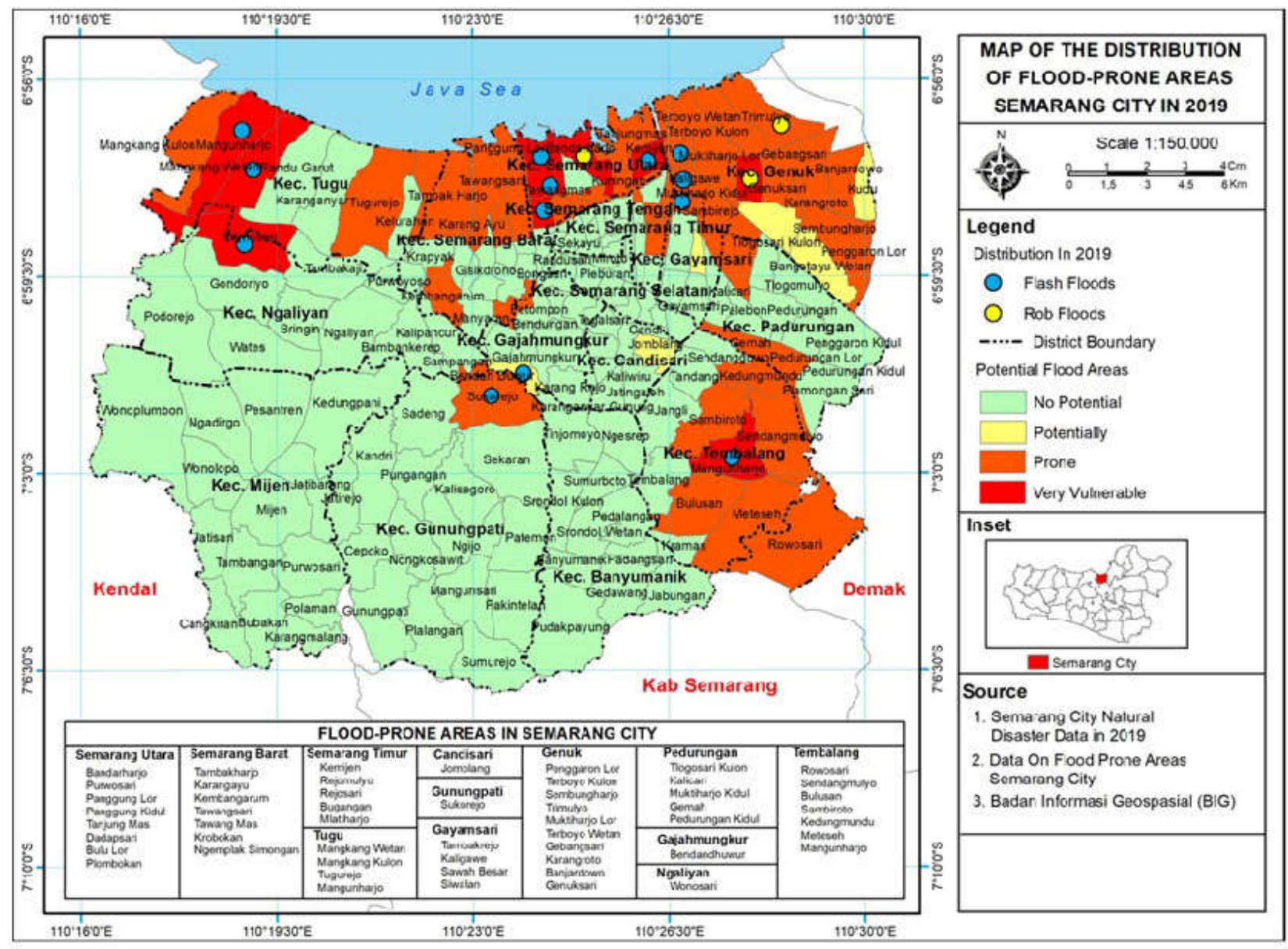

Figure 1. The distribution of flood and flood-affected area in Semarang City 
the snowball sampling method. The data includes millennials' attitudes, perspectives of the flood, disaster management, and metacognitive abilities in dealing with flood

Questionnaire statements were modified using the Guttman scale based on the Metacognitive Awareness Inventory (MAI) that was developed by Schraw \& Dennison, (1994) (Table 2). Each question was completed with specific rubrics to make it easier for respondents to answer in the same perception. It is an instrument designed to measure general self-regulated learning skills transversely on the various disciplines.

The MAI procedure was used because it has cleared descriptions and grouped knowledge of the cognitions. The assessment of disaster management strategies was conducted by observing current activities that has already conducted for youth participant in the research locus, and the activities derived from Regulation of the Republic of Indonesia Number 24 Year 2007 about Disaster Management (Supplementation Table 1). This regulation is the main legislation law that used by Indonesian National Board for Disaster Management to establish disaster management activities (Ali et al., 2019; Maulida, 2020). Then, in this research, both MAI and Regulation No. 24 Year 2007 were breaking down and regrouped based on the similarity and congruence activity. The regrouped procedure was also based on the knowledge from metacognition that required to run disaster management activities. After regrouped, the validity and reliability were measured using Pearson's linear correlation performed using SPSS 21. The $\mathrm{R}$ score was measured to analyze observed indicator item's power or how much the observed indicators compose latent variable. Field observations were carried to measure disaster management activity which is conducted by millennials.

There were 51 questions of metacognitive awareness developed from MAI sheet, and 35 questions of flood disaster management were developed from indicator activities (Supplementation Tabel 2). The questions were first analyzed the validity and reliability of the instrument regarding data collection and calculation, was run using Pearson's analysis and linear Regression with confident interval 95\%. Both MAI and flood disaster questions were aligned based on epistemic alignment process, it was conducted through discussion involving several experts in education, psychologic, and disaster management fields. All obtained data were collected and proceeded into coding, tabulation, and screening stages.

The obtained data was statistically analyzed using nonparametric: Mann-Whitney test to determine differences of millennials' metacognitive knowledge from affected and flooded areas. The statistical analysis was conducted using SPSS 23 for Mac. After that, the statistical result was followed up with interpretation and explanation from in-depth interview. The statistical and in-depth interview data were then qualitatively analyzed with the taxonomy model to categorize multifaced and complex information to common conceptual domains and dimensions (Patton, 2014).

\section{Result and Discussion}

In this study, the measured metacognition consist of two aspects, there was Cognitive Knowledge (CoK) and Controlling Knowledge (CnK). The aspects of $\mathrm{CoK}$ were then define into three types, 1) declaration knowledge (DK), 2) procedural knowledge $(\mathrm{PK})$, and 3) conditional knowledge (CK). The highest value of CoK was found in CK aspect, in both groups. CK is the most prominent aspect compared to other aspects. This research has been conducted involving more than 248 respondents and it was categorized by ages, gender, education level, and frequency of flood (Table 3).

The respondents were dominated by millennials aged 1418 years old and most of them were women. Whereas, for comparison, respondents from both areas were high school students. The information in this research were grouped

Table 1.The number of respondents per district of Semarang City

\begin{tabular}{|c|c|c|c|c|}
\hline \multirow{2}{*}{ District } & \multicolumn{2}{|c|}{ Flooded or Affected Area } & \multicolumn{2}{|c|}{ No or Less Potential } \\
\hline & $\sum$ Resp. & $\%$ & $\sum$ Resp. & $\%$ \\
\hline Banyumanik* & - & - & 15 & 13.89 \\
\hline Candisari $^{\star}$ & - & - & 10 & 9.26 \\
\hline Mijen* & - & - & 13 & 12.04 \\
\hline Ngaliyan & 15 & 10.71 & 10 & 9.26 \\
\hline Pedurungan & 14 & 10.00 & 5 & 4.63 \\
\hline East Semarang & 15 & 10.71 & 6 & 5.56 \\
\hline Gajah Mungkur & 8 & 5.71 & 6 & 5.56 \\
\hline Gunungpati & - & - & 12 & 11.11 \\
\hline Gayamsari & 12 & 8.57 & 6 & 5.56 \\
\hline Genuk & 12 & 8.57 & - & - \\
\hline Central Semarang & 11 & 7.86 & 6 & 5.56 \\
\hline North Semarang & 15 & 10.71 & - & - \\
\hline Tembalang & 15 & 10.71 & - & - \\
\hline Tugu & 13 & 9.29 & 5 & 4.63 \\
\hline South Semarang & - & - & 12 & 11.11 \\
\hline West Semarang & 10 & 7.14 & 2 & 1.85 \\
\hline Total & 140 & 100.00 & 108 & 100.00 \\
\hline
\end{tabular}


Table 2 . The modification of metacognitive awareness inventory (MAI) based on disaster management strategy in Semarang City.

\begin{tabular}{|c|c|}
\hline Metacognitive Component & Description and observed focused-skill in flood disaster management \\
\hline \multicolumn{2}{|l|}{ Cognitive Knowledge (CoK) } \\
\hline \multirow[t]{2}{*}{ Declarative Knowledge (DK) } & It refers to general factual information. \\
\hline & $\begin{array}{l}\text { In this study, millennials' understanding refers to their knowledge on flood disaster manage- } \\
\text { ment; intellectual resources, and abilities as millennials to participate in disaster manage- } \\
\text { ment. }\end{array}$ \\
\hline \multirow[t]{2}{*}{ Procedural Knowledge (PK) } & $\begin{array}{l}\text { This knowledge assesses the action for completing a procedure or implementing process/ } \\
\text { strategies. It requires millennials' knowledge on the process, and when to apply it in various } \\
\text { situations. }\end{array}$ \\
\hline & $\begin{array}{l}\text { In this research, the researcher was observed millennials' action in standard operational pro- } \\
\text { cedures of disaster management. This knowledge can be used to explain how far millennials } \\
\text { obtain their knowledge, discovery skill, cooperation in a group, and problem-solving skill. }\end{array}$ \\
\hline \multirow[t]{2}{*}{ Conditional Knowledge (CK) } & $\begin{array}{l}\text { This knowledge regarding when a procedure, skill or strategy is used and when it is not used, } \\
\text { how procedure can be used under certain conditions, and why a procedure is better than } \\
\text { another procedure. }\end{array}$ \\
\hline & $\begin{array}{l}\text { In this research, the observation was conducted to assess millennials' competencies on mak- } \\
\text { ing decision during critical situation of flood disaster. }\end{array}$ \\
\hline \multicolumn{2}{|l|}{ Controlling Knowledge (CnK) } \\
\hline Planning $(\mathrm{P})$ & $\begin{array}{l}\text { It includes all activities on strategy planning, goal setting, and allocating resources to over- } \\
\text { come problems, including disaster damage impact }\end{array}$ \\
\hline $\begin{array}{l}\text { Information Management } \\
\text { Strategies (IMS) }\end{array}$ & $\begin{array}{l}\text { It depicts how millennials using their skill on organizing, elaborating, summarizing, to get } \\
\text { selective focus to process an information, efficiently. }\end{array}$ \\
\hline $\begin{array}{l}\text { Comprehension Monitoring } \\
(\mathrm{CM})\end{array}$ & $\begin{array}{l}\text { The regulation assessing how does strategy use by millennials to check up whether the disas- } \\
\text { ter management procedure is run in the right track or not. }\end{array}$ \\
\hline Debugging Strategies (DS) & It relates to various strategies that applied by millennials to recognize and correct errors \\
\hline Evaluation (E) & $\begin{array}{l}\text { This knowledge is more analyzing about post assessment of self-participation, performance, } \\
\text { and strategy effectiveness after disaster management implementation }\end{array}$ \\
\hline
\end{tabular}

Table 3. Number of respondents by demographic characteristics

\begin{tabular}{|c|c|c|c|c|}
\hline \multirow{2}{*}{ Demographic } & \multicolumn{2}{|c|}{ Affected or Flooded Area } & \multicolumn{2}{|c|}{ No or Less Potential-Flooded Area } \\
\hline & $\sum$ Resp. & $\%$ & $\sum$ Resp. & $\%$ \\
\hline \multicolumn{5}{|l|}{ Ages (years old) } \\
\hline $14-17$ & 71 & 65,74 & 125 & 89,29 \\
\hline $18-21$ & 25 & 23,15 & 15 & 10,71 \\
\hline $21-24$ & 12 & 11,11 & - & \\
\hline \multicolumn{5}{|l|}{ Gender } \\
\hline Male & 41 & 37,96 & 37 & 26,43 \\
\hline Female & 67 & 62,04 & 103 & 73,57 \\
\hline \multicolumn{5}{|l|}{ Educational levels } \\
\hline High School & 74 & 68,52 & 114 & 81,43 \\
\hline University & 34 & 31,48 & 26 & 18,57 \\
\hline \multicolumn{5}{|l|}{ Flooded frequency } \\
\hline Never & 10 & 9,26 & 126 & 90,00 \\
\hline$<3$ times/ month & 68 & 62,96 & 14 & 10,00 \\
\hline 3-5 times/ month & 14 & 12,96 & & \\
\hline$>5$ times/ month & 16 & 14,81 & & \\
\hline
\end{tabular}


based on the flood impact in respondents environment. This study only focus on the flooding frequency and how community develop their metacognition

We grouped all of the MAI questions into six category activities representing flood disaster management activities. The grouped phase has decided based on the conceptual domain, and the possibility of the metacognition aspects that may contribute to the management activities. To ensure the MAI effectiveness in measuring respondent's knowledge, we analyse the instrument before used for observation session. Based on the validity and reliability analysis, all of the instrument were capable to be applied in data collection, and has stated as valid and reliable questions to measure metacognitive knowledge related to flood disaster management activities, except question number 25 about debugging strategy in MAI sheet (Table 4). The invalid question may cause by too general question, that make no variation answer from the respondents, and it was no high enough to measure the youth perception. In other word, all of the respondent has same perception and answer in same choice. After the validation process the invalid question was withdrew from measuring components of metacognitive aspect in mitigation, emergency respond and rehabilitation skill.

In this research we were not apply all of the MAI question items to the activities in the same number. The several knowledges were not appropriate to compose the activities, for example procedural knowledge (PK) was not applicable for mitigation, rehabilitation skill and program evaluation. The evaluation knowledge (E) was only compatible for composing program evaluation (Table 4). We also found that all knowledge score was higher in preparation activities in millennials in flooded area than flooded-affected areas. Both the comprehension monitoring (CM) and the debugging strategies (DS) has no significant differences in all aspect in all respondents in both areas.

The metacognitive strategy is a strategy that invites understanding and thinking in designing the process of solving problems comprehensively, implementing and evaluating it (Heyes, 2016). In the flood disaster management, metacognitive strategy includes aspects of knowledge about when and how to use certain strategies to deal with the disasters. The metacognitive stimulates people to develop knowledge through experiences (Chekwa et al., 2015; Frank \& Kuhlmann, 2016),_and learning process from behavior adaptation against conflicts (Questienne et al., 2018). It also makes the analysis skill in mitigation and adaptation getting deeper to create a decision in overcome the disaster (Kumar et al., 2019). Furthermore, the development of higher-level, complex and metacognitive thinking skills can help solve problems or make decision in disaster management (Brooks et al., 2016; Kumar et al., 2019).

The MAI's questions as the observed variables were regrouped to arrange an assessment of the flood disaster management. We found there were same knowledge aspects can be used to represent in different flood disaster management activities (Table 5). It proved that metacognitive is a multidimensional knowledge that may composed together and expressed during thinking about problems and actions. It may also contribute in composing high quality actions that can be performed by comprehensive step from planning, monitoring to evaluating. Based on the observation, the millennials portray narrow understanding about disaster management an still focus on the actions after the disaster. The CK is

Table 4.Validity and correlation (R-score) of metacognitive awareness inventory in composing disaster management activity instrument

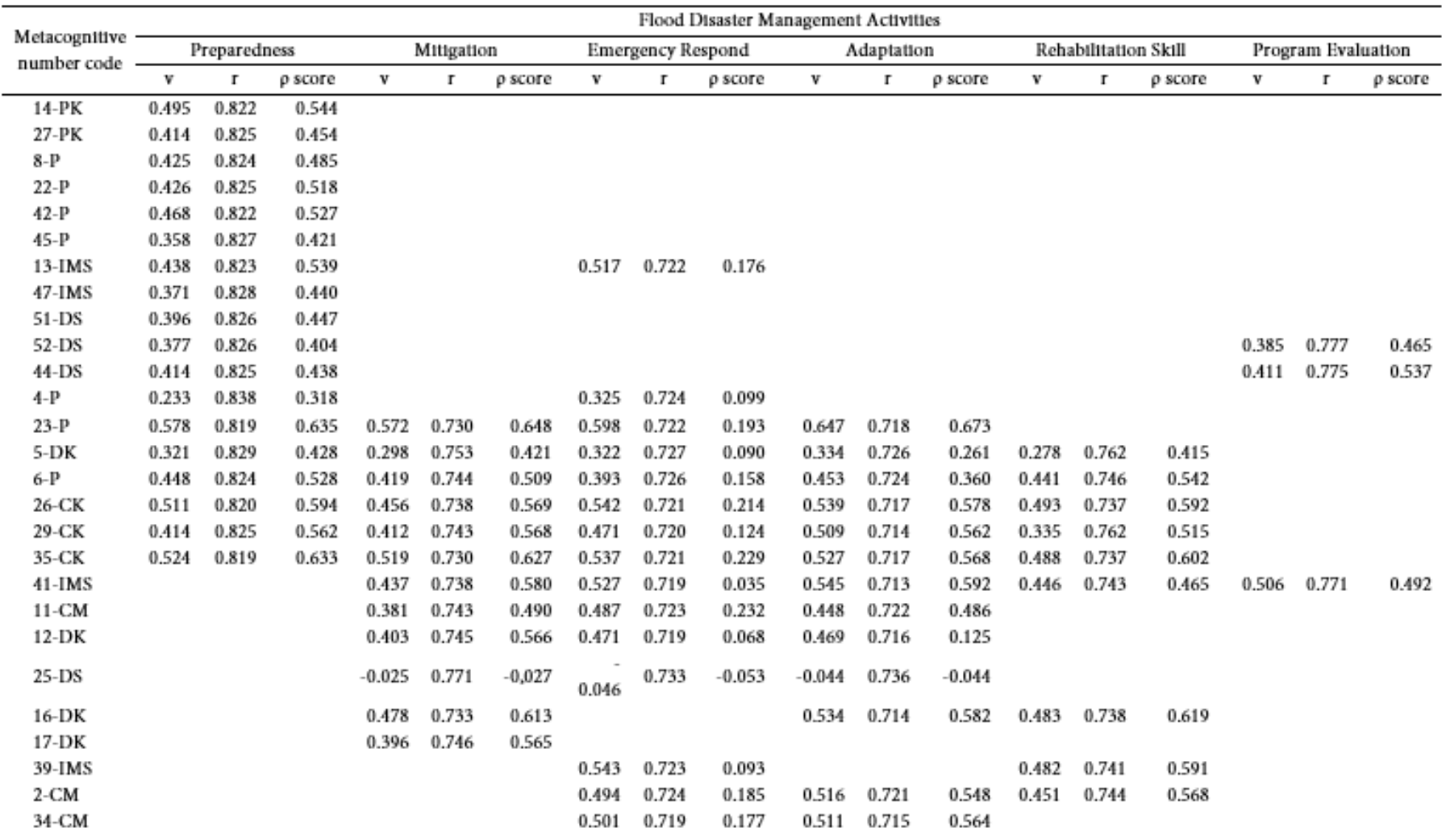


Continue Table 4.Validity and correlation (R-score).........

\begin{tabular}{|c|c|c|c|c|c|c|c|c|c|c|c|c|c|c|c|c|c|c|}
\hline \multirow{3}{*}{$\begin{array}{l}\text { Metacognittve } \\
\text { number code }\end{array}$} & \multicolumn{18}{|c|}{ Flood Disaster Management Activities } \\
\hline & \multicolumn{3}{|c|}{ Preparedness } & \multicolumn{3}{|c|}{ Mitigation } & \multicolumn{3}{|c|}{ Emergency Respond } & \multicolumn{3}{|c|}{ Adaptation } & \multicolumn{3}{|c|}{ Rehabilitation Skill } & \multicolumn{3}{|c|}{ Program Evaluatton } \\
\hline & $\mathrm{v}$ & $\mathrm{r}$ & $\rho$ score & $\mathbf{v}$ & $\mathrm{r}$ & $\rho$ score & $\mathrm{v}$ & $r$ & $\rho$ score & $\mathbf{v}$ & $\mathrm{r}$ & $\rho$ score & $\mathrm{v}$ & $r$ & $\rho$ score & $\mathbf{v}$ & $r$ & $\rho$ score \\
\hline 3-PK & & & & & & & 0.419 & 0.723 & 0.180 & 0.384 & 0.722 & 0.438 & & & & & & \\
\hline 9-IMS & & & & & & & 0.162 & 0.729 & 0.071 & & & & & & & & & \\
\hline 10-DK & & & & & & & 0.457 & 0.722 & 0.252 & & & & & & & & & \\
\hline 18-CK & & & & & & & 0.404 & 0.725 & 0.108 & & & & & & & & & \\
\hline 20-DK & & & & & & & 0.480 & 0.719 & 0.152 & & & & & & & & & \\
\hline 28-CM & & & & & & & 0.512 & 0.720 & 0.124 & & & & & & & & & \\
\hline 33-PK & & & & & & & 0.607 & 0.717 & 0.168 & & & & & & & & & \\
\hline 37-IMS & & & & & & & 0.297 & 0.725 & 0.179 & & & & & & & & & \\
\hline 40-DS & & & & & & & 0.378 & 0.727 & 0.152 & & & & & & & & & \\
\hline 46-DK & & & & & & & 0.600 & 0.721 & 0.237 & & & & & & & & & \\
\hline 48-IMS & & & & & & & 0.365 & 0.723 & 0.229 & & & & & & & & & \\
\hline 30-IMS & & & & & & & & & & 0.415 & 0.721 & 0.465 & & & & & & \\
\hline 31-IMS & & & & & & & & & & 0.476 & 0.719 & 0.522 & & & & & & \\
\hline 43-IMS & & & & & & & & & & 0.502 & 0.720 & 0.540 & & & & & & \\
\hline $15-\mathrm{CK}$ & & & & & & & & & & & & & 0.457 & 0.744 & 0.544 & & & \\
\hline 49-CM & & & & & & & & & & & & & 0.324 & 0.759 & 0.598 & & & \\
\hline 1-CM & & & & & & & & & & & & & & & & 0.312 & 0.783 & 0.464 \\
\hline 7-E & & & & & & & & & & & & & & & & 0.421 & 0.773 & 0.517 \\
\hline $19-\mathrm{E}$ & & & & & & & & & & & & & & & & 0.342 & 0.780 & 0.478 \\
\hline 21-CM & & & & & & & & & & & & & & & & 0.394 & 0.777 & 0.587 \\
\hline 24-E & & & & & & & & & & & & & & & & 0.358 & 0.782 & 0.487 \\
\hline 32-DK & & & & & & & & & & & & & & & & 0.428 & 0.773 & 0.554 \\
\hline $36-\mathrm{E}$ & & & & & & & & & & & & & & & & 0.492 & 0.766 & 0.602 \\
\hline $38-\mathrm{E}$ & & & & & & & & & & & & & & & & 0.508 & 0.765 & 0.591 \\
\hline 50-E & & & & & & & & & & & & & & & & 0.425 & 0.773 & 0.598 \\
\hline
\end{tabular}

Note: The observed indicators items stated as a valid question for measuring the metacognitive in flood disaster management activities if the validation score ( $\mathrm{v}$ ) above 0.273 ( $\mathrm{R}$ table score for $\alpha$ : 0.05 ); and the reliable ( $\mathrm{r}$ ) score confirm the observed indicators items' reliability in composing assessment for metacognitive in flood disaster management indicator, the items stated reliable if the r score above R table score. The " $\rho$ score" is representing Pearson's linier correlation score per observed indicator item compared to the total observed indicators per flood disaster management activities, The items stated correlate and able to measure flood disaster management activities if the " $\rho$ score" bellow Cronbach's alpha score for each activities. The Cronbach's alpha per each activity were: 0.832 for Preparedness, 0.760 for Mitigation, 0.732 for Emergency Respond, 0.733 for Adaptation, 0.764 for Rehabilitation, and 0.777 for Evaluation.

main knowledge that expressed by the respondents in management planning, mitigation activity, emergency responses, adaptation activity, and rehabilitation when they facing the flood. For example, the flash flood is frequently occurring in coastal area of Semarang City, the respondent in that areas were more responsive and developed early warning activities when the hard rain occurs and river water level raises. They already built up an early warning system to raise their resilience by monitoring the water level in the floodgate and disseminating the information of water raises to the other community members. The citizen in affected areas will follow up the information by securing and evacuate their precise belonging, they will also consciously be gathered to the assembly site. It because, citizen in the area of the flash flood such as in Tugu District and Wonosari subdistrict, Ngaliyan District has already received empowered program and developed flood early warning system (Sari \& Prayoga, 2018).

Generally, the higher score performed in CK followed with $\mathrm{PK}$, it means that the respondents totally understand the situation and how to act. Based on these conditions, it is likely that the millennial generation has knowledge of factual conditions in disasters. This shows that the cognitive ability in the information that is owned by the information received is well developed (Park et al., 2020; Torrens-Burton et al., 2017). Several cases obtained from the observation that knowledge about flood disasters, on the basis of learning from schools and or media coverage. An interesting fact found in the field is that respondents have high evaluative knowledge related to disaster preparedness processes, but do not see imperfections in disaster response implementation as problems that need to be corrected. It may cause by lack of formal platform for millennials to give ideas and inputs in term of contingency plan revision. Even though millennial participation in disaster management may give a flexibility and dynamic effect in the implementation of disaster preparedness action in community. This has an impact on the active participation of millennials, which is likely to help disaster risk reduction campaigns (Octastefani \& Rum, 2019). The interesting fact is high respond of the disaster management implementation was performed by the respondent at the ages of 21-24 years old. We assumed that at those ages, they are considered as a part of community and accepted by elder members either younger generation. In other case, millennials are required to be independently and actively collect disaster information, to act quickly and precisely, because have a vital role in pre and post disaster (Fernandez \& Shaw, 2015). Similar with the findings about the relationship between metacognitive knowledge and learning, shows that overall responses have higher CK than PK (Mastrothanais et al., 2018). 
Table 5. Respondent's metacognition aspect score age, gender, education level, and affected by flood

\begin{tabular}{|c|c|c|c|c|c|c|c|c|}
\hline \multirow{2}{*}{$\begin{array}{c}\text { Disaster Management } \\
\text { Activities }\end{array}$} & \multicolumn{3}{|c|}{$\mathrm{CoK}$} & \multicolumn{5}{|c|}{$\mathrm{CnK}$} \\
\hline & $\mathrm{DK}$ & $\mathrm{PK}$ & $\mathrm{CK}$ & $\mathrm{P}$ & IMS & $\mathrm{CM}$ & DS & $\mathrm{E}$ \\
\hline \multicolumn{9}{|l|}{ Affected Area } \\
\hline Preparation & $67.77^{\mathrm{a}}$ & $82.33^{\mathrm{a}}$ & $77.11^{\mathrm{a}}$ & $75.98^{a}$ & $75.82^{\mathrm{a}}$ & $\mathrm{n} / \mathrm{a}$ & 86.45 & $\mathrm{n} / \mathrm{a}$ \\
\hline Mitigation & $72.17^{a}$ & $\mathrm{n} / \mathrm{a}$ & 79.78 & $79.33^{a}$ & 76.67 & 89.01 & 98.67 & $\mathrm{n} / \mathrm{a}$ \\
\hline Emergency Respond & 77.73 & 76.37 & 83.87 & 82.67 & 74.67 & 84.00 & 95.33 & $\mathrm{n} / \mathrm{a}$ \\
\hline Adaptation & $76.00^{\mathrm{a}}$ & 71.43 & 79.78 & 91.67 & 82.00 & 84.67 & 98.00 & $\mathrm{n} / \mathrm{a}$ \\
\hline Rehabilitation Skill & 82.33 & $\mathrm{n} / \mathrm{a}$ & 82.67 & 91.33 & 84.33 & 86.67 & $\mathrm{n} / \mathrm{a}$ & $\mathrm{n} / \mathrm{a}$ \\
\hline Program Evaluation & 85.33 & $\mathrm{n} / \mathrm{a}$ & $\mathrm{n} / \mathrm{a}$ & $\mathrm{n} / \mathrm{a}$ & 81.33 & 75.00 & 90.00 & $73.63^{\mathrm{a}}$ \\
\hline No or Less Potential & & & & & & & & \\
\hline Preparation & $75.56^{\mathrm{b}}$ & $89.01^{\mathrm{b}}$ & $80.95^{b}$ & $80.39^{b}$ & $81.87^{\mathrm{b}}$ & $\mathrm{n} / \mathrm{a}$ & 88.64 & $\mathrm{n} / \mathrm{a}$ \\
\hline Mitigation & $77.20^{\mathrm{b}}$ & $\mathrm{n} / \mathrm{a}$ & 80.95 & $92.31^{\mathrm{b}}$ & 73.63 & 91.33 & 98.90 & $\mathrm{n} / \mathrm{a}$ \\
\hline Emergency Respond & 78.90 & 83.33 & 85.05 & 82.78 & 72.34 & 84.34 & 97.25 & $\mathrm{n} / \mathrm{a}$ \\
\hline Adaptation & $80.59^{b}$ & 88.00 & 80.95 & 92.31 & 83.52 & 86.45 & 98.90 & $\mathrm{n} / \mathrm{a}$ \\
\hline Rehabilitation Skill & 83.52 & $\mathrm{n} / \mathrm{a}$ & 84.34 & 94.51 & 81.32 & 87.36 & $\mathrm{n} / \mathrm{a}$ & $\mathrm{n} / \mathrm{a}$ \\
\hline Program Evaluation & 89.01 & $\mathrm{n} / \mathrm{a}$ & $\mathrm{n} / \mathrm{a}$ & $\mathrm{n} / \mathrm{a}$ & 80.77 & 79.12 & 87.91 & $80.22^{b}$ \\
\hline
\end{tabular}

Note: the alphabet ( $\mathrm{a} \& \mathrm{~b}$ ) represent the significantly different between groups

Disaster management is a systematic and comprehensive effort to cope with all disaster events quickly, accurately and to suppress victims and losses (Carter, 1991). In another term, disaster management describes activities includes observing and analyzing disasters to improve actions, in order to strengthen the strategies on prevention, reduction, preparation, emergency response and recovery (Lettieri et al., 2009). All of the strategies has objectives include: 1) reducing or avoiding social, economic loses (Adeagbo et al., 2016), mental, and physical health (Shultz \& Galea, 2008); 2) reducing the suffering of disaster victims; 3) speed up recovery; 4) providing protection to refugees or people who are displaced when their lives are threatened (Chan, 2015).

In fact, the majority of the respondents, actively participates in mitigation through tree and mangrove rehabilitation, cleaning up beaches from plastic and developing community based early warning system. But we found that most of their internal motivation is not strong because mostly of them just followed their friend and has no initiative in their own community movement. It needs to be recognized that millennials are still less involved in several activity such as disaster management plant preparation and evaluation. Even though, millennials skill in collecting and distributing information, also facilitating external assistance is very important to help in post-disaster activities include recovery, rehabilitation, and reconstruction (Wen et al., 2018). In another side, less involvement of millennials reduces their awareness in rehabilitation action (Ali et al., 2019; Shariff \& Hamidi, 2019).

The observation shown, there were low participation in post-disaster traumatic rehabilitation, It caused by assumption appears in community that there are no mental disorder occurs after the flood, and the flood as general natural event. In fact, the perception that post-disaster trauma is considered an over-response and not a dangerous problem (Akerkar \& Fordham, 2017). The low reporting of mental health conditions after the flood disaster may lead to low management of psychological trauma and more emphasis on infrastructure development. This has implications for the difficulty of diagnosing mental illness and rehabilitation efforts. The majority of respondents also thought that it was impolite to ask about the psychological condition of disaster victims because this condition was a personal problem. This condition is common in developing countries or rural areas as a result of low mental health literacy, inadequate mental health treatment in terms of experts and facilities, the influence of social stigma (DupontReyes et al., 2020), fear of being considered crazy by the community, taboo in discussing mental problems (Hartini et al., 2018), and low economic income (Crumb et al., 2019). Therefore, there needs to be fundamental improvements that need to be made, especially in the fields of knowledge, education and training in resolving post-disaster trauma (Morganstein \& Ursano, 2020).

Ideally, millennials who has high access to technology, can take advantages to overcome trauma, increase consciousness and create opportunities for victims to gain up their motivation through creative ways. But, even the millennials in Semarang City has access to internet and social media, they do not show actively in rehabilitation services, such as improving mobility or mental health for kids. It may cause by lack of self-drive, feeling reluctant and lacking in courage, as well as the lack of involvement from related parties to mobilize youth as volunteers in post-disaster activities (Bloom, 2017; Keller, 2016).

\section{Conclusion}

The millennials in flood disaster areas in Semarang City have a high ability to manage strategies in dealing with foodrelated problems. This is indicated by the high value of DS which represents the corrective attitude and ability to think quickly which is represented in the value of CK. For metacognitive awareness, the cognition knowledge is higher than controlling knowledge, it can be concluded that most of 
the millennials are know and understand about disaster management, but in fact, they less involved in flood disaster management planning. We believe, all knowledge in metacognitive is related, or even applied during implementing the disaster management.

Generally, the respondent has low score of the metacognitive on preparedness and emergency respond. Most of the respondent actively involved in mitigation and rehabilitation as a volunteer in ecosystem rehabilitation, but they have lack initiative to personally taking action in their own environment. It indicates that millennials knowledge should be sharpen by increasing their awareness and knowledge toward involved in various disaster experiences.

The millennials with metacognitive skills will tend to learn disaster management strategies based on previous successes or failures in completing tasks. In other words, millennials shall be more actively, independently, and cooperatively involved in arranging flood-disaster management. But we also realize that in this research still lack of information, such as how shall community elements, including millennials involved in build up community-based disaster resilience.

\section{Acknowledgement}

The author would like to acknowledge to the Institute for Research and Community Services for facilitating this research through DIPA funding Universitas Negeri Semarang in 2020.

\section{References}

Adeagbo, A., Daramola, A., Carim-Sanni, A., Akujobi, C., \& Ukpong, C. (2016). Effects of natural disasters on social and economic well being: A study in Nigeria. International Journal of Disaster Risk Reduction, 17(August 2016). 1-12. https:// doi.org/10.1016/j.ijdrr.2016.03.006

Akerkar, S., \& Fordham, M. (2017). Gender, place and mental health recovery in disasters: Addressing issues of equality and difference. International Journal of Disaster Risk Reduction, 23 (July 2016). 218-230. https://doi.org/10.1016/j.ijdrr.2017.03.014

Ali, M. S. S., Arsyad, M., Kamaluddin, A., Busthanul, N., \& Dirpan, A. (2019). Community based disaster management: Indonesian experience. IOP Conference Series: Earth and Environmental Science, 235(1). https://doi.org/10.1088/1755$1315 / 235 / 1 / 012012$

Bloom, P. (2017). Empathy and its discontents. Trends in Cognitive Sciences, 21(1). 24-31. https://doi.org/10.1016/j.tics.2016.11.004

BNPB. (2021). Informasi Bencana. Available on line at: https:// www.bnpb.go.id/informasi-bencana

BPBD. (2021). Data Bencana Tahun 2012-2020. Available on line at: http://bpbd.semarangkota.go.id/pages/data-bencana

Brooks, B., Curnin, S., Bearman, C., Owen, C., \& Rainbird, S. (2016). An assessment of the opportunities to improve strategic decision-making in emergency and disaster management. Australian Journal of Emergency Management, 31(4). 38-43.

Buchori, I., Pramitasari, A., Sugiri, A., Maryono, M., Basuki, Y., \& Sejati, A. W. (2018). Adaptation to coastal flooding and inundation: Mitigations and migration pattern in Semarang City, Indonesia. Ocean and Coastal Management, 163(August 2018). 445-455.

https://doi.org/10.1016/ j.ocecoaman.2018.07.017

Carter, W. N. (1991). Disaster management a disaster manager's handbook. Asian Development Bank: Mandaluyong City, Philiphine: . https://www.think-asia.org/bitstream/ handle/11540/5035/disaster-management-handbook.pdf? sequence $=1$

Chan, N. W. (2015). Impacts of disasters and disaster risk management in Malaysia: the case of floods. In Resilience and Recovery in Asian Disasters (239-265). Springer: Tokyo. https:// doi.org/10.1007/978-4-431-55022-8

Chaussard, E., Amelung, F., Abidin, H., \& Hong, S. H. (2013). Sinking cities in Indonesia: Alos Palsar detects rapid subsidence due to groundwater and gas extraction. Remote Sensing of Environment, 128(January 2013). 150-161. https:// doi.org/10.1016/j.rse.2012.10.015

Chekwa, E., McFadden, M., Divine, A., \& Dorius, T. (2015). Metacognition: Transforming the learning experience. Journal of Learning in Higher Education, 11(2). 109-112. http:// search.ebscohost.com/login.aspx? direct $=$ true $\& \mathrm{db}=$ eue $\& A \mathrm{~N}=110908492 \&$ site $=$ ehost-live

Cox, R. S., \& Hamlen, M. (2015). Community disaster resilience and the rural resilience index. American Behavioral Scientist, 59(2). 220-237. https://doi.org/10.1177/0002764214550297

Cox, R. S., Hill, T. T., Plush, T., Heykoop, C., \& Tremblay, C. (2019). More than a checkbox: engaging youth in disaster risk reduction and resilience in Canada. Natural Hazards, 98(1). 213-227. https://doi.org/10.1007/s11069-018-3509-3

Crumb, L., Mingo, T. M., \& Crowe, A. (2019). "Get over it and move on": The impact of mental illness stigma in rural, low-income United States populations. Mental Health and Prevention, 13 (November 2018). 143-148. https://doi.org/10.1016/ j.mhp.2019.01.010

Dupont-Reyes, M. J., Villatoro, A. P., Phelan, J. C., Painter, K., \& Link, B. G. (2020). Adolescent views of mental illness stigma. American Journal of Orthopsychiatry, 90(2). 201-211. http:// dx.doi.org/10.1037/ort0000425

Fernandez, G., \& Shaw, R. (2015). Youth participation in disaster risk reduction through science clubs in the Philippines. Disasters, 39(2). 279-294. https://doi.org/10.1111/disa.12100

Fletcher, S., Cox, R. S., Scannell, L., Heykoop, C., Tobin-Gurley, J., \& Peek, L. (2016). Youth creating disaster recovery and resilience: A multi-site arts-based youth engagement research project. Children, Youth and Environments, 26(1). 148-163. https://doi.org/10.7721/chilyoutenvi.26.1.0148

Fothergill, A. (2020). Children, youth, and disaster. Oxford Research Encyclopedia of Natural Hazard Science. Available on line at: https://oxfordre.com/naturalhazardscience/view/10.1093/ acrefore/9780199389407.001.0001/acrefore-9780199389407-e23.

Frank, D. J., \& Kuhlmann, B. G. (2016). More than just beliefs $\bigotimes$ : Experience and beliefs jointly contribute to volume effects on metacognitive judgments. Journal of Experimental Psychology: Learning, Memory, and Cognition, 43(5). 680-694.

Ganapati, N. E., \& Mostafavi, A. (2018). Cultivating metacognition in each of us: thinking about "thinking" in interdisciplinary disaster research. Risk Analysis. 0(0). 1-19. https:// doi.org/10.1111/risa.13226

Hapsari, R. I., \& Zenurianto, M. (2016). View of flood disaster management in Indonesia and the key solutions. American Journal of Engineering Research (AJER), 5(3). 140-151. http:// www.ajer.org/papers/v5(03)/T050301400151.pdf

Hartini, N., Fardana, N. A., Ariana, A. D., \& Wardana, N. D. (2018). Stigma toward people with mental health problems in Indonesia. Psychology Research and Behavior Management, 11 (Oktober 2018). 535-541. https://doi.org/10.2147/ PRBM.S175251

Heyes, C. (2016). Who knows? Metacognitive social learning strategies. Trends in Cognitive Sciences, 20(3). 204-213. https:// doi.org/10.1016/j.tics.2015.12.007

Indrayati, A., Aji, A., \& Hikmah, N. (2018). 3D model and morphometry of the Beringin watershed as an effort for flash flood disaster risk reduction in Semarang. MATEC Web of Conferences, 229. https://doi.org/10.1051/ matecconf/201822904010

Ivanova, O. E. (2019). Critical thinking in the digital age: Strategies of human resource management. Space and Culture, India, 7(3). 139-148. https://doi.org/10.20896/saci.v7i3.658 
Janicke-Bowles, S., Nayaran, A., \& Seng, A. (2018). Social media for good? A survey on millennials' inspirational social media use. The Journal of Social Media in Society, 7(2). 120-140.

Kavousi, S., Miller, P. A., \& Alexander, P. A. (2019). Modeling metacognition in design thinking and design making. International Journal of Technology and Design Education. 30(4).709-735. https://doi.org/10.1007/s10798-019-095219

Keller, R. S. (2016). Keeping disaster human: empathy, systematization, and the law. Minnesota Journal of Law, Science \& Technology, 17(1), 1-69. Available on line at: https://scholarship.law.umn.edu/mjlst/voll7/iss1/1

The

Koumachi, B. (2019). The digital turn in higher education: A "digital natives" mythbusting. International Journal of Research in English Education, 4(1). 69-79.

Kudesia, R. S. (2019). Mindfulness as metacognitive practice. Academy of Management Review, 44(2). 405-423. https:// doi.org/10.5465/amr.2015.0333

Kumar, S. A. P., Bao, S., Singh, V., \& Hallstrom, J. (2019). Flooding disaster resilience information framework for smart and connected communities. Journal of Reliable Intelligent Environments, 5(1). 3-15. https://doi.org/10.1007/s40860019-00073-2

Lettieri, E., Masella, C., \& Radaelli, G. (2009). Disaster management: Findings from a systematic review. Disaster Prevention and Management: An International Journal, 18(2). 117136. https://doi.org/10.1108/09653560910953207

Liu, W., Dugar, S., Mccallum, I., Thapa, G., See, L., Khadka, P., Budhathoki, N., Brown, S., Mechler, R., Fritz, S., \& Shakya, P. (2018). Integrated participatory and collaborative risk mapping for enhancing disaster resilience. ISPRS International Journal of GeoInformation, 7(2). 1-23. https://doi.org/10.3390/ ijgi7020068

Mark, P. (2017). Environmental disruption: Push/pull factors, human migration, and homeland security. Journal of Political Sciences \& Public Affairs, 5(2).624-629. https:// doi.org/10.4172/2332-0761.1000264

Mastrothanais, K., Kalianou, M., Katsifi, S., \& Zouganali, A. (2018). The use of metacognitive knowledge and regulation strategies of students with and without special learning difficulties. International Journal of Special Education, 33 (1). 184-200. Available on line at: https://eric.ed.gov/? id $=\mathrm{EJ} 1184100$

Maulida, H. (2020). The implementation of disaster management and legal protection for disaster relief volunteers (Case of Central Java Province, Indonesia). Journal of Law and Legal Reform, 1(3). 415-424. https://doi.org/10.15294/ jllr.v1i3.37091

Morganstein, J. C., \& Ursano, R. J. (2020). Ecological Disasters and Mental Health: Causes, Consequences, and Interventions. Frontiers in Psychiatry, 11(February 2020). 1-15. https:// doi.org/10.3389/fpsyt.2020.00001

Naubi, I., Zardari, N. H., Shirazi, S. M., Roslan, N. A., Yusop, Z., \& Haniffah, M. R. B. M. (2017). Ranking of Skudai river subwatersheds from sustainability indices-Application of promethee method. International Journal of GEOMATE, 12(29). 124-131. https://doi.org/10.21660/2017.29.24734

Nifa, F. A. A., Abbas, S. R., Lin, C. K., \& Othman, S. N. (2017). Developing a disaster education program for community safety and resilience: The preliminary phase. AIP Conference Proceedings, 1891(October 2017). https:// doi.org/10.1063/1.5005338

Nugraha, A. L., Hani'Ah, \& Pratiwi, R. D. (2017). Assessment of multi hazards in Semarang City. AIP Conference Proceedings, 1857, 1-9. https://doi.org/10.1063/1.4987112

Nugraha, S. B., Sidiq, W. A. B. N., \& Hanafi, F. (2017). Landsat image analysis for open spaces change monitoring to temperature changes in Semarang City. 1st International
Conferenve on Geography and Education, 79, 212-217. https://doi.org/10.2991/icge-16.2017.43

O’Neill, H. K., McLean, A. J., Kalis, R., \& Shultz, J. M. (2016). Disaster averted: Community resilience in the face of a catastrophic flood. Disaster Health, 3(3). 67-77. https:// doi.org/10.1080/21665044.2016.1219575

Octastefani, T., \& Rum, M. (2019). Millennials' contribution in disaster risk reduction: Case study of tidal flooding in Semarang. Jurnal Ilmu Sosial Dan Ilmu Politik, 23(1). 1429. https://doi.org/10.22146/jsp.43727

Ozsoy, G., Memis, A., \& Temur, T. (2009). Metacognition, study habits and attitudes. International Electronic Journal of Elementary Education, 2(1). 154-166.

Park, B., Korbach, A., \& Brünken, R. (2020). Does thinking-aloud affect learning, visual information processing and cognitive load when learning with seductive details as expected from self-regulation perspective? Computers in Human Behavior, 111(10). 106411. https:// doi.org/10.1016/j.chb.2020.106411

Patton, M. Q. (2014). Qualitative Research \& Evaluation Methods: Integrating Theory and Practice (4th ed.). SAGE Publications. https://books.google.co.id/books?id=CM9BQAAQBAJ

Questienne, L., Van Opstal, F., Van Dijck, J. P., \& Gevers, W. (2018). Metacognition and cognitive control: Behavioural adaptation requires conflict experience. Quarterly Journal of Experimental Psychology, 71(2), 411-423. https:// doi.org/10.1080/17470218.2016.1251473

Rahmayanti, H., Ichsan, I. Z., Azwar, S. A., Damayanti, S., Suharini, E., \& Kurniawan, E. (2020). Environmental learning about flood disaster in university: Students HOTS for preliminary analysis to develop DIFMOL model. E3S Web of Conferences, 211, 1-8. https://doi.org/10.1051/ e3sconf $/ 202021102016$

Rico, G. C. S. (2019). School-community collaboration: Disaster preparedness towards building resilient communities. International Journal of Disaster Risk Management, 1(2). 45-59. https://doi.org/10.18485/ijdrm.2019.1.2.4

Roy, S. G., Tucker, G. E., Koons, P. O., Smith, S. M., \& P. Upton. (2016). A fault runs through it: Modeling the influence of rock strength and grain-size distribution in a faultdamaged landscape. Journal of Geophysical Research: Earth Surface, 121(10). 1911-1930. https:// doi.org/10.1002/2013JF002871.Received

Sari, A. D., \& Prayoga, N. (2018). Enhancing citizen engagement in the face of climate change risks: A case study of the flood early warning system and health information system in Semarang city, Indonesia. In S. Hughes (Ed.), Climate Changes in Cities: Urban Book Series (121-137). https:// doi.org/10.1007/978-3-319-65003-6_7

Schraw, G., \& Dennison, R. S. (1994). Assessing metacognitive awareness. In Contemporary Educational Psychology, 19 (4).460-475. https://doi.org/10.1006/ceps.1994.1033

Shariff, N. N. M., \& Hamidi, Z. S. (2019). Community-based approach for a flood preparedness plan in Malaysia. Jàmbá: Journal of Disaster Risk Studies, 11(1). 1-6. https:// doi.org/10.4102/jamba.v11i1.598

Shea, N., \& Frith, C. D. (2019). The global workspace needs metacognition. Trends in Cognitive Sciences, 23(7). 560571. https://doi.org/10.1016/j.tics.2019.04.007.

Shultz, J. M., \& Galea, S. (2008). Financial and social circumstances and the incidence and course of PTSD in Mississippi during the first two years after Hurricane Katrina. Journal of Traumatic Stress, 21(4). 357-368. https:// doi.org/10.1002/jts.20355

Suharini, E., Hanafi, F., Sidiq, A. B. N., \& Wahid, W. (2017). Study of population growth and land use change impact of intrusion on Pekalongan City. Advances in Social Science, Education and Humanities Research, 79(ICGE 2016), 232238. https://doi.org/10.2991/icge-16.2017.46 
Suharini, E., Kurniawan, E., \& Ichsan, I. Z. (2020). Disaster mitigation education in the COVID-19 pandemic: A case study in indonesia. Sustainability (United States), 13(6). 292-298. https://doi.org/10.1089/sus.2020.0053

Tjahjono, H., Suripin, M., \& Kismartini, M. (2018). Strategies for determining priority area for mitigation of landslide disaster in Semarang City. International Conference on Rural Studies in Asia (ICoRSIA), 313(ICoRSIA 2018). 301-305. https:// doi.org/10.2991/icorsia-18.2019.72

Torrens-Burton, A., Basoudan, N., Bayer, A. J., \& Tales, A. (2017). Perception and reality of cognitive function: Information processing speed, perceived memory function, and perceived task difficulty in older adults. Journal of Alzheimer's Disease, 60 (4). 1601-1609. https://doi.org/10.3233/JAD-170599

Wen, J.-C., Huang, S.-Y., Hsu, C.-C., Hsiao, M.-C., Schismenos, S., Hung, J.-H., Chang, Y.-W., Lin, K.-W., Chen, Y.-C., Chang, T.P., Shih, M.-H., \& Wang, P.-S. (2018). Identifying disaster risk. In Science and Technology in Disaster Risk Reduction in Asia. (111-123). Elsevier Inc. https://doi.org/10.1016/b978-0-12812711-7.00008-0

Yulianto, T., Suripin, S., \& Purnaweni, H. (2019). Zoning landslide vulnerable area according to geological structure, slopes, and landuse parameters in Trangkil Sukorejo Gunungpati Semarang City's Residental Area. Journal of Physics: Conference Series, 1217(012029). https://doi.org/10.1088/1742$6596 / 1217 / 1 / 012029$

Zweers, J. (2019). The Impact of Landslides on The Public Awareness of Children: A Phenomenological case study in the city of Semarang, Indonesia [Radboud University Nijmegen]. https:// theses.ubn.ru.nl/bitstream/handle/123456789/8746/Bachelor Thesis GPE_JolienZweers.pdf? sequence $=1$ 